\title{
Congenital heart disease in Down's syndrome
}

\author{
H. Bakgaard Laursen \\ From the Departments of Cardiology and Paediatrics, University Hospital, Arhus, Denmark
}

Eighty cases of Down's syndrome were found among 1504 children with congenital heart disease under the age of 15 years. The most common cardiac anomaly, ventricular septal defect, was found in 49 per cent of the 80 cases studied, while the second most frequently encountered anomaly, common atrioventricular canal, was found in 15 per cent. Haemodynamic investigations of 24 cases of ventricular septal defect showed Eisenmenger's syndrome to be present in 10 cases; this seemed to appear at an earlier age in mongoloid children than in other children with ventricular septal defect. Right-toleft shunt was found in 5 out of 9 cases of common atrioventricular canal. Pulmonary hypertension was found in all of 24 cases of ventricular septal defect and in 7 of 9 cases of common atrioventricular canal. The cumulative survival up to 10 years was 64 per cent for girls and 49 per cent for boys. Death was most commonly the result of pulmonary complications which occurred in 22 out of the 34 patients who died.

The high incidence of congenital heart disease in Down's syndrome is well known, and many authors have published figures on the frequency with which congenital heart defects are found. These figures vary from 7 to 70 per cent (Berg, Crome, and France, 1960; Evans, 1950; Liu and Corlett, 1959; Rowe, 1962; Rowe and Uchida, 1961; Øster, 1953). The varying results of these studies may be because different groups of patients are not directly comparable. The incidence is highest in necropsy series and lowest in clinical groups, where special methods of investigation, such as heart catheterization, were not used. Mongolism occurs more often in Caucasians than in other races (Engle and Ehlers, 1968). Øster (1956) estimated the incidence to be 0.16 per cent among live births in a Danish study. Boesen et al. (1963) found the frequency of mongolism to be 4.7 per cent (29 patients) in a clinical study of 615 children with congenital heart disease.

\section{Present study}

This study was undertaken: 1) to obtain more information about the nature of heart defects associated with Down's syndrome, 2) to describe the haemodynamics in groups of patients with ventricular septal defects and common atrioventricular canal, and 3) to estimate the mortality and causes of death.

Received 19 June 1975. 
patients died later without subsequent necropsy, a final diagnosis could not be made.

The incidence of various major cardiovascular abnormalities is seen in Table 1. The largest group is ventricular septal defect $(49 \%)$, and the next largest is common atrioventricular canal of the complete type (19\%). The major cardiac malforma-

TABLE 1 Incidence of major cardiovascular malformations in 80 children with Down's syndrome: distribution of similar lesions in children in same age group (Keith et al., 1958) is shown for comparison

\begin{tabular}{llc}
\hline Cardiac malformation & This study & $\begin{array}{c}\text { Keith et al. } \\
(1958)\end{array}$ \\
\hline $\begin{array}{l}\text { Ventricular septal defect } \\
\text { Common atrioventricular }\end{array}$ & $39(49 \%)$ & $25 \%$ \\
$\quad$ canal & $15(19 \%)$ & $2 \%$ \\
Tetralogy of Fallot & $6(8 \%)$ & $11 \%$ \\
Atrial septal defect & $3 \star(4 \%)$ & $7 \%$ \\
Persistent ductus arteriosus & $5(6 \%)$ & $17 \%$ \\
Pulmonary stenosis & $3(4 \%)$ & $7 \%$ \\
Primary pulmonary hyper- & $2(2 \%)$ & \\
$\quad$ tension & $1(1 \%)$ & $6 \%$ \\
Coarctation of aorta & $1(1 \%)$ \\
Mitral stenosis and regurgi- & $1(1 \%)$ \\
$\quad$ tation & $4(5 \%)$ \\
Vascular ring & $80(100 \%)$ \\
No diagnosis & \\
\hline
\end{tabular}

«Two of these 3 patients had an ostium primum atrial septal defect. In the third the type was uncertain from the necropsy report (no catheterization). tions were accompanied by other cardiovascular lesions in several cases, as shown in Table 2.

\section{Haemodynamics}

The results of heart catheterization of patients with ventricular septal defect and common atrioventricular canal are shown in Tables 3, 4, and 5. The uncomplicated ventricular septal defects have been classified as described by Kidd et al. (1965) (shown to the left in Table 3 and in Table 5). Group 1 contains ventricular septal defects with a small shunt (pulmonary blood flow/systemic blood flow $<2 / 1$ ) and normal pulmonary vascular resistance. Group 2 comprises ventricular septal defects with moderate sized or large shunts (pulmonary blood flow/systemic blood flow >2/1) and the pulmonary vascular resistance varying from low to high. Group 3 is made up of ventricular septal defects with small shunts (pulmonary blood flow/systemic blood flow $<2 / 1$ ) and high pulmonary vascular resistance. Group 4 includes patients with rightto-left or mixed shunts and high pulmonary vascular resistance (Eisenmenger's syndrome). Heart catheterization was performed in 24 patients with ventricular septal defects $(14$ boys and 10 girls). The age of the children varied from 2 months to 140 months and the mean age was 54 months. Ten patients were found to have Eisenmenger's syndrome. Twenty-three patients had pulmonary hypertension (systolic pulmonary artery pressure $>40 \mathrm{mmHg}(5.3 \mathrm{kPa})$. In one case the pulmonary artery pressure could not be measured but the

TABLE 2 Coexisting cardiac malformations in 67 children† with Down's syndrome and congenital heart disease

\begin{tabular}{|c|c|c|c|c|c|}
\hline \multirow{2}{*}{ Major cardiac malformation } & \multicolumn{3}{|c|}{ Coexisting cardiac malformations } & \multirow[b]{2}{*}{$\begin{array}{l}\text { Coarctation of } \\
\text { aorta }\end{array}$} & \multirow[b]{2}{*}{ Other lesions } \\
\hline & $\begin{array}{l}\text { No. of } \\
\text { cases }\end{array}$ & $\begin{array}{l}\text { Persistent ductus } \\
\text { arteriosus }\end{array}$ & $\begin{array}{l}\text { Atrial septal } \\
\text { defect }\end{array}$ & & \\
\hline Ventricular septal defect & 32 & 5 & 6 & 1 & $\begin{array}{l}\text { Malformation of } \\
\text { tricuspid valve (1) }\end{array}$ \\
\hline Common atrioventricular canal & 15 & 1 & 1 & 1 & $\begin{array}{l}\text { Valvar pulmonary } \\
\text { stenosis }(1)\end{array}$ \\
\hline Atrial septal defect & 3 & & & 1 & \\
\hline $\begin{array}{l}\text { Primary pulmonary } \\
\text { hypertension }\end{array}$ & 2 & & $1 *$ & & \\
\hline Coarctation of aorta & 1 & 1 & & & \\
\hline Vascular ring & 1 & 1 & & & $\begin{array}{l}\text { Small ventricular } \\
\text { septal defect (1) }\end{array}$ \\
\hline $\begin{array}{l}\text { Tetralogy of Fallot } \\
\text { Persistent ductus arteriosus }\end{array}$ & $\begin{array}{l}6 \\
5\end{array}$ & & 1 & & \\
\hline Pulmonary stenosis & 2 & & 1 & & \\
\hline Total & 67 & 8 & 10 & 3 & 3 \\
\hline
\end{tabular}

fOnly those patients in whom the nature of the cardiac abnormalities was determined by heart catheterization or necropsy are included in the Table.

*Pulmonary hypertension could not be attributed to the small atrial septal defect. 
TABLE 3 Results of heart catheterization in 24 patients with Down's syndrome and ventricular septal defect

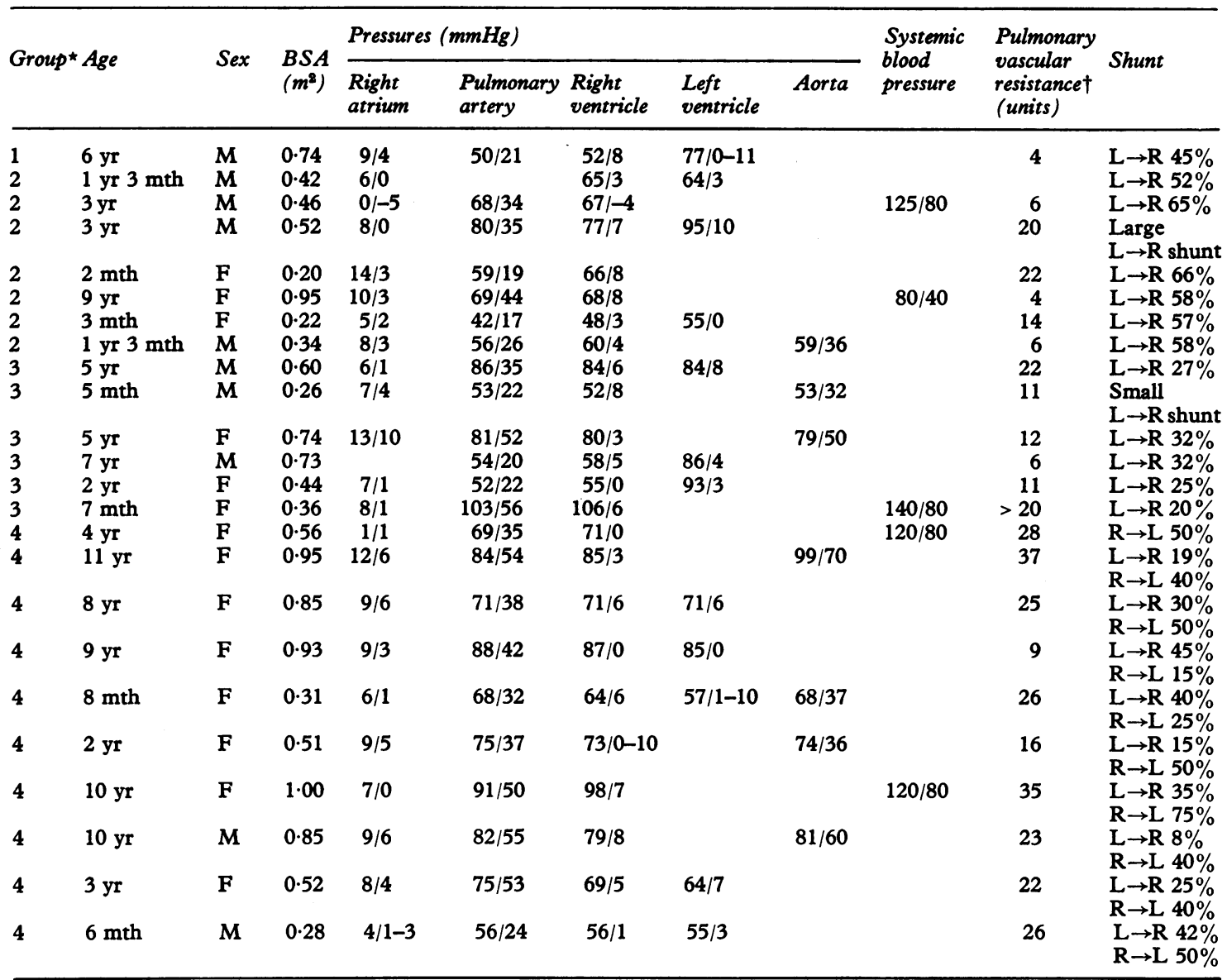

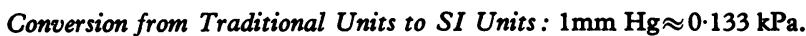

*Classification of Kidd et al. (1965).

†Pulmonary vascular resistance expressed in units ( $\mathrm{mm} \mathrm{Hg} /$ pulmonary blood flow in litres per minute).

TABLE 4 Grouping of 24 cases of ventricular septal defect in Down's syndrome, and of 398 cases of ventricular septal defect (Kidd et al., 1965)

\begin{tabular}{lll}
\hline & Kidd et al. (1965) & This study \\
\cline { 2 - 3 } Group * & No. of patients & No. of patients \\
\hline 1 & $123(31 \%)$ & $1(4 \%)$ \\
2 & $240(60 \%)$ & $7(29 \%)$ \\
3 & $14(4 \%)$ & $6(25 \%)$ \\
4 & $21(5 \%)$ & $10(42 \%)$ \\
\hline Total & 398 & 24
\end{tabular}

*Classification of Kidd et al. (1965). right ventricular pressure was found to be raised, and angiocardiography did not show valvar pulmonary stenosis. In 9 patients the pulmonary hypertension was severe (pulmonary artery pressure $>75 \mathrm{mmHg}(10.0 \mathrm{kPa})$ systolic).

Heart catheterization was performed in 9 patients with common atrioventricular canal (Table 5). Five patients had right-to-left or mixed shunts, and 7 patients had pulmonary hypertension. There were 6 boys and 3 girls in the group, varying in age from 3 months to 106 months, with a mean age of 59 months.

Operability and surgery

After heart catheterization the operability of all 
TABLE 5 Results of heart catheterization in 9 patients with Down's syndrome and common atrioventricular canal

\begin{tabular}{|c|c|c|c|c|c|c|c|c|c|}
\hline \multirow[b]{2}{*}{ Age } & \multirow[b]{2}{*}{ Sex } & \multirow[b]{2}{*}{$\begin{array}{l}B S A \\
\left(m^{2}\right)\end{array}$} & \multicolumn{5}{|c|}{ Pressures (mmHg) } & \multirow{2}{*}{$\begin{array}{l}\text { Pulmonary } \\
\text { vascular } \\
\text { resistance } \\
\text { (units) }\end{array}$} & \multirow[b]{2}{*}{ Shunt } \\
\hline & & & $\begin{array}{l}\text { Right } \\
\text { atrium }\end{array}$ & $\begin{array}{l}\text { Pulmonary } \\
\text { artery }\end{array}$ & $\begin{array}{l}\text { Right } \\
\text { ventricle }\end{array}$ & $\begin{array}{l}\text { Left } \\
\text { ventricle }\end{array}$ & Aorta & & \\
\hline $\begin{array}{l}4 \mathrm{yr} \\
4 \mathrm{yr} \\
3 \mathrm{mth}\end{array}$ & $\begin{array}{l}\mathbf{M} \\
\mathbf{M} \\
\mathbf{F}\end{array}$ & $\begin{array}{l}0.71 \\
0.69 \\
0.19\end{array}$ & $\begin{array}{r}14 / 6 \\
8 / 5 \\
8 / 4\end{array}$ & $\begin{array}{l}30 / 16 \\
15 / 9 \\
53 / 27\end{array}$ & $\begin{array}{l}66 / 5 \\
87 / 4 \\
57 / 3\end{array}$ & $\begin{array}{l}87 / 4 \\
58 / 2\end{array}$ & $67 / 40$ & $\begin{array}{r}3 \\
4 \\
>30\end{array}$ & \multirow{6}{*}{ 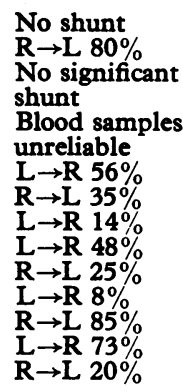 } \\
\hline $1 \mathrm{yr} 6 \mathrm{mth}$ & $\mathbf{M}$ & 0.44 & $19 / 7$ & $100 / 59$ & $100 / 17$ & $104 / 15$ & & $?$ & \\
\hline $8 \mathrm{yr}$ & $\mathbf{M}$ & 0.74 & $16 / 2$ & $86 / 45$ & $83 / 16$ & $87 / 15$ & & 14 & \\
\hline $\begin{array}{l}77 \mathrm{yr} \\
10 \mathrm{yr}\end{array}$ & $\underset{\mathbf{F}}{\mathbf{F}}$ & $\begin{array}{l}0.84 \\
0.85\end{array}$ & $\begin{array}{l}8 / 3 \\
6 / 3\end{array}$ & $\begin{array}{l}48 / 17 \\
76 / 43\end{array}$ & $\begin{array}{l}42 / 5 \\
77 / 0\end{array}$ & $100 / 0$ & $77 / 58$ & $\begin{array}{r}8 \\
11\end{array}$ & \\
\hline $6 \mathrm{yr}$ & $\mathbf{M}$ & 054 & $6 / 4$ & $69 / 39$ & $69 / 3$ & $69 / 3$ & & 37 & \\
\hline $4 \mathrm{mth}$ & $M$ & 0.22 & $7 / 4$ & $51 / 18$ & $66 / 1$ & $67 / 4$ & & 19 & \\
\hline
\end{tabular}

Conversion from traditional units to $S I$ units: $1 \mathrm{mmHg} \approx 0.133 \mathrm{kPa}$.

patients was assessed. The results are shown in Table 6. In 2 patients with ventricular septal defect operation was not recommended because of severe mental retardation. The parents refused operation for one case of persistent ductus arteriosus and for one case of atrial septal defect.

During the period of this study 16 operations were performed, but several patients are still waiting for surgery.

\section{Mortality}

Life expectancy tables up to age 10 years have been constructed for girls and boys, the children entering the tables at birth. Cumulative survival rates are shown in Tables 7 and 8 , and illustrated in the Figure. The mortality is very high during the first year of life, with only 61 per cent of the boys and 71 per cent of the girls surviving this period. After one year of age the curve becomes flatter and after 10 years the cumulative survival for girls is 64 per cent and 49 per cent for boys. This study has shown no significant sex difference in the cumulative survival using the Mantel Haensel test (Ipsen and Feigl, 1970). $\left(\chi^{2}\right.$ 1.14. $\left.P>0 \cdot 2\right)$. The causes of death are shown in Table 9. Of 16 patients operated on, 6 have died, and of the 16 patients found inoperable at the time of heart catheterization, 2 have died.

\section{Discussion}

It has long been known that common atrioventricular canal and ventricular septal defect are common cardiac malformations in patients with Down's syndrome (Tandon and Edwards, 1973). Defects in the atrioventricular canal, atrial septal defects of the secundum type, and ventricular septal defects comprised 80 per cent of all cardiac malformations in a group of British patients evaluated at necropsy (Berg et al., 1960). In the prospective study of Rowe and Uchida (1961), the most frequent anomaly was defect in the atrioventricular

TABLE 6 Assessment of operability in 48 patients with Down's syndrome and congenital heart disease

\begin{tabular}{lllll}
\hline Cardiac anomaly & $\begin{array}{l}\text { No. of } \\
\text { patients }\end{array}$ & $\begin{array}{l}\text { Indication for } \\
\text { operation }\end{array}$ & $\begin{array}{l}\text { No indication } \\
\text { for operation }\end{array}$ & \begin{tabular}{c} 
Inoperable \\
\hline Ventricular septal defect
\end{tabular} \\
Common atrioventricular canal & 24 & 10 & 3 & 11 \\
Tetralogy of Fallot & 9 & 3 & 3 & 3 \\
$\begin{array}{l}\text { Persistent ductus arteriosus } \\
\text { Atrial septal defect }\end{array}$ & 5 & 5 & & \\
Primary pulmonary hypertension & 2 & 2 & & 2 \\
Mitral stenosis and regurgitation & 2 & & 1 & 16 \\
\hline Total & 1 & 25 & 7 & \\
\hline
\end{tabular}


TABLE 7 Life expectancy table for 41 girls with Down's syndrome and congenital heart disease

\begin{tabular}{|c|c|c|c|c|c|c|c|}
\hline $\begin{array}{l}\text { Age interval } \\
\text { (yrs) }\end{array}$ & $\begin{array}{l}\text { Alive at start } \\
\text { of interval }\end{array}$ & $\begin{array}{l}\text { Live with- } \\
\text { drawals during } \\
\text { interval }\end{array}$ & $\begin{array}{l}\text { At risk of death } \\
\text { during interval }\end{array}$ & $\begin{array}{l}\text { Deaths during } \\
\text { interval }\end{array}$ & Death rate & Survival rate & $\begin{array}{l}\text { Cumulative } \\
\text { survival rate }\end{array}$ \\
\hline $0-1$ & 41 & 0 & $41 \cdot 0$ & 11 & 0.27 & 0.73 & 1.00 \\
\hline $1-2$ & 30 & 2 & $29 \cdot 0$ & 1 & 0.03 & 0.97 & 0.73 \\
\hline $2-3$ & 27 & 0 & $27 \cdot 0$ & 0 & 0.00 & 1.00 & 0.71 \\
\hline $3-4$ & 27 & 0 & $27 \cdot 0$ & 0 & 0.00 & 1.00 & 0.71 \\
\hline $4-5$ & 27 & 2 & $27 \cdot 0$ & 0 & 0.00 & 1.00 & 0.71 \\
\hline $5-6$ & 25 & 2 & $24 \cdot 0$ & 1 & 0.04 & 0.96 & 0.71 \\
\hline $6-7$ & 22 & 2 & $21 \cdot 0$ & 0 & 0.00 & 1.00 & 0.68 \\
\hline $7-8$ & 20 & 1 & $19 \cdot 5$ & 0 & 0.00 & 1.00 & 0.68 \\
\hline 8-9 & 19 & 2 & $18 \cdot 0$ & 0 & 0.00 & 1.00 & 0.68 \\
\hline $9-10$ & 17 & 2 & $16 \cdot 0$ & 1 & 0.06 & 0.94 & 0.68 \\
\hline $10-11$ & 14 & 3 & $12 \cdot 5$ & 1 & 0.08 & 0.92 & 0.64 \\
\hline
\end{tabular}

TABLE 8 Life expectancy table for 39 boys with Down's syndrome and congenital heart disease

\begin{tabular}{|c|c|c|c|c|c|c|c|}
\hline $\begin{array}{l}\text { Age interval } \\
\text { (yrs) }\end{array}$ & $\begin{array}{l}\text { Alive at start } \\
\text { of interval }\end{array}$ & $\begin{array}{l}\text { Live with- } \\
\text { drawals during } \\
\text { interval }\end{array}$ & $\begin{array}{l}\text { At risk during } \\
\text { interval }\end{array}$ & $\begin{array}{l}\text { Deaths during } \\
\text { interval }\end{array}$ & Death rate & Survival rate & $\begin{array}{l}\text { Cumulative } \\
\text { survival rate }\end{array}$ \\
\hline $0-1$ & 39 & 1 & $38 \cdot 5$ & 15 & 0.39 & 0.61 & 1.00 \\
\hline $1-2$ & 23 & 0 & 23.0 & 0 & 0.00 & 1.00 & 0.61 \\
\hline $2-3$ & 23 & 3 & $21 \cdot 5$ & 0 & 0.00 & 1.00 & $0 \cdot 61$ \\
\hline $3-4$ & 20 & 1 & $19 \cdot 5$ & 0 & 0.00 & 1.00 & 0.61 \\
\hline $4-5$ & 19 & 0 & $19 \cdot 0$ & 0 & 0.00 & 1.00 & 0.61 \\
\hline $5-6$ & 19 & 3 & $17 \cdot 5$ & 2 & $0 \cdot 11$ & 0.89 & 0.61 \\
\hline $6-7$ & 14 & 2 & 13.0 & 0 & 0.00 & 1.00 & 0.54 \\
\hline $7-8$ & 12 & 3 & $10 \cdot 5$ & 1 & $0 \cdot 10$ & 0.90 & 0.54 \\
\hline $8-9$ & 8 & 4 & 6.0 & 0 & 0.00 & 1.00 & 0.49 \\
\hline $9-10$ & 4 & 1 & 3.5 & 0 & 0.00 & 1.00 & 0.49 \\
\hline $10-11$ & 3 & 2 & 1.5 & 0 & 0.00 & $1 \cdot 00$ & 0.49 \\
\hline
\end{tabular}

TABLE 9 Cause of death in 34 patients with Down's syndrome and congenital heart disease

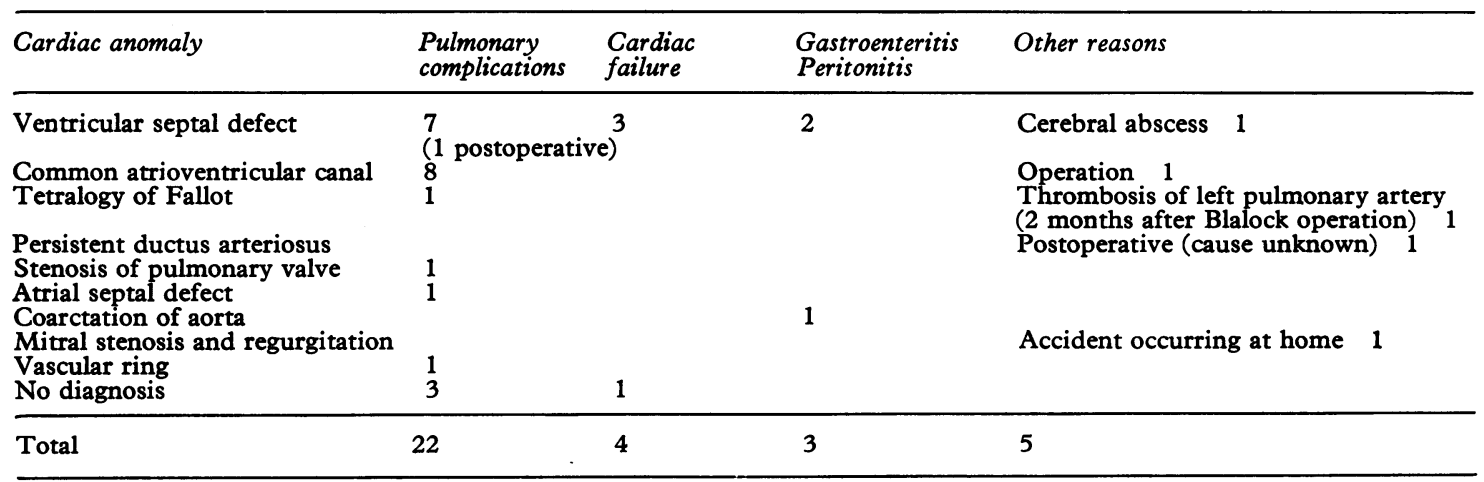




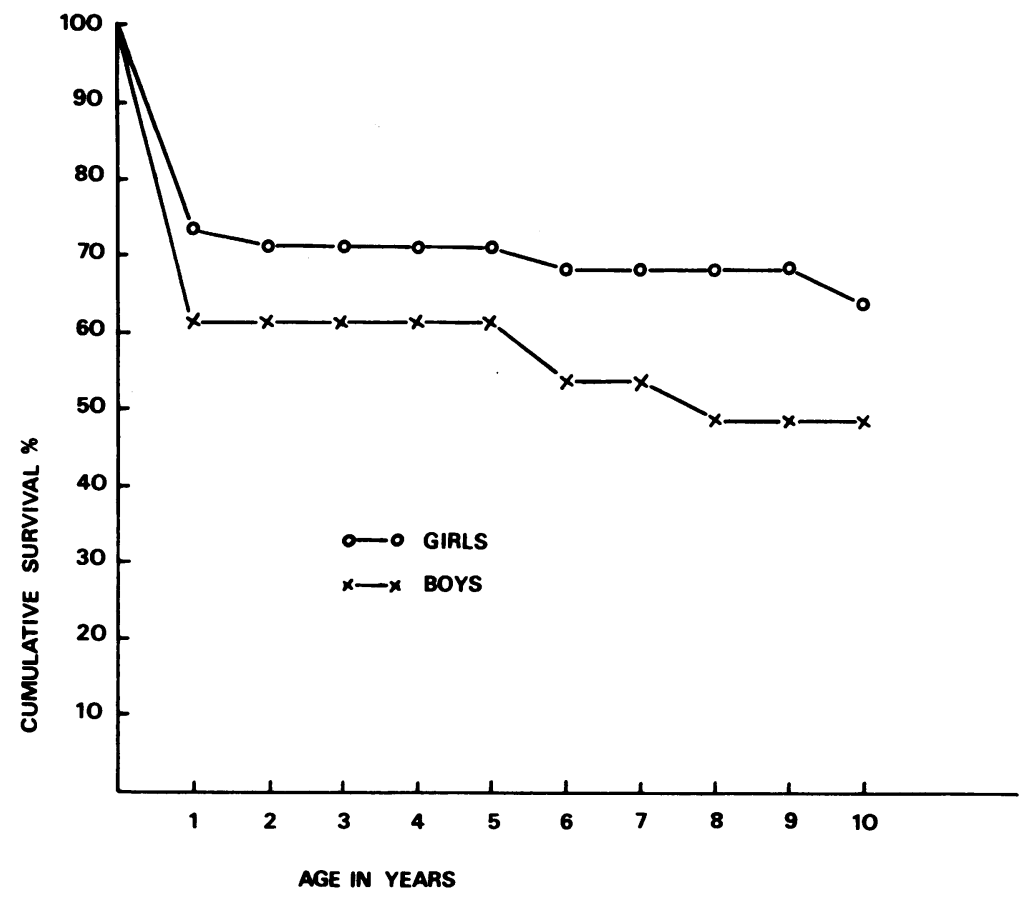

FIG. Cumulative survival for first 10 years of life in 41 girls and 39 boys with congenital heart disease and Doun's syndrome.

canal (36\%), and ventricular septal defects were found in 33 per cent. Our results are similar to those of other workers. Table 1 shows the figures of Keith, Rowe, and Vlad (1958) describing children with congenital heart disease in the same age group as the patients in this study. The most striking differences are that ventricular septal defect is more frequent and common atrioventricular canal much more frequent in Down's syndrome. In the present investigation 28 coexisting cardiovascular malformations were found in 67 patients. However, there is no reason to believe that this figure differs from that found in nonmongoloid children with congenital heart disease (Berg et al., 1960).

Few haemodynamic investigations in patients with Down's syndrome and congenital heart disease have been published ( $\mathrm{Chi}$ and Krovetz, 1975; Kreutzer et al., 1973; Liu and Corlett, 1959; Shaher et al., 1972; Soudon et al., 1975). Though pulmonary hypertension and Eisenmenger's syndrome have been known to occur in mongolism the exact incidence is difficult to assess. This study shows that a greater number of ventricular septal defects than would be expected (Kidd et al., 1965) fall into groups 3 and 4 (Eisenmenger's syndrome), and only a small portion into group 2, which in non-mongoloid children is the largest group (Table 4). It may be argued that this difference results from the high proportion of patients with associated cardiovascular malformations in this series. Excluding such cases, the total number is reduced to 13 , but the distribution of patients in the different groups is not essentially altered, 4 cases (31\%) falling in group 4 and 4 cases in group 3. No cases of Eisenmenger's syndrome were found in the study of Kidd et al. (1965) before the age of 2 years, while in the present study 2 cases were diagnosed at an earlier age (viz. 6 and 8 months). Shaher et al. (1972) also found that 76 per cent of patients with Down's syndrome and ventricular septal defect or common atrioventricular canal (10 out of 13 patients) had Eisenmenger's syndrome (patients with right-to-left or bidirectional shunts). If such patients are included in the present material, the total number of Eisenmenger's syndrome would be 45 per cent (15 of 33 patients). Thus, our data confirm the observation that more patients with Down's syndrome and ventricular septal defect develop Eisenmenger's syndrome than do non-mongoloid children with the same cardiac anomaly and that this occurs at an earlier age. In this study pulmonary hypertension was found in all 24 cases 
of ventricular septal defect and in 7 of 9 cases of common atrioventricular canal. These findings are in accordance with those of Soudon et al. (1975) who found an earlier and greater increase of pulmonary vascular resistance in mongoloid children with ventricular septal defect (10 patients) than in non-mongoloids. Chi and Krovetz (1975) found that the mean pulmonary artery pressure was raised in 20 of 24 patients with Down's syndrome and ventricular septal defect. If patients with Down's syndrome who have ventricular septal defects or common atrioventricular canal are considered for surgical correction, it is recommended that they undergo cardiac catheterization at an earlier age than non-mongoloid children. The early surgery might then prevent the development of pulmonary vascular disease and right-toleft or mixed shunt. It is possible that the pulmonary vessels in mongoloid children are more sensitive to raised pressure in the pulmonary circulation than those of non-mongoloid children, though Plett, Tandon, and Moller (1974) could not find any major histological difference between pulmonary vessels in patients with common atrioventricular canal and mongolism and those in patients without mongolism. Thus, pulmonary hypertension in these children is not adequately understood, and more investigations are needed.

The results of the present investigation, which includes operated and unoperated patients, show a higher survival rate at 10 years than in the investigation of Fabia and Drolette (1970), who found 45 per cent of the boys and 32 per cent of the girls with Down's syndrome and congenital heart disease surviving the first 10 years of life, while 75 per cent of the patients without congenital heart disease were alive at the age of 10 years. The observed difference in mortality may be the result of a disparity in the selection of patients in the 2 studies, as no information is given about the types of congenital heart disease in Fabia and Drolette's series, and there may have been more serious malformations than in the present study. In our series, there was a lower mortality in females, whereas Fabia and Drolette reported a significantly lower survival rate for females from age 2 upwards.

Table 9, which lists the causes of death, shows that 22 of the 34 patients died from pulmonary complications. Infection in the respiratory tract is a common complication in patients with Down's syndrome, both with and without congenital heart disease. Liu and Corlett (1959) showed that in 19 of 22 mongoloid children without congenital heart disease death was the result of pulmonary complications.

\section{References}

Berg, J. M., Crome, L., and France, N. E. (1960). Congenital cardiac malformations in mongolism. British Heart fournal, 22, 331 .

Boesen, I., Melchior, J. C., Terslev, E., and Vendel, S. (1963). Extracardiac congenital malformations in children with congenital heart diseases. Acta Paediatrica, Suppl. $146,28$.

Chi, T. L., and Krovetz, J. (1975). The pulmonary vascular bed in children with Down syndrome. Fournal of Pediatrics, 86, 533.

Engle, M. A., and Ehlers, K. H. (1968). Cardiovascular malformations in association with chromosomal aberrations. In Paediatric Cardiology, p. 694. Ed. by H. Watson. Lloyd-Luke, London.

Evans, P. R. (1950). Cardiac anomalies in mongolism. British Heart fournal, 12, 258.

Fabia, J., and Drolette, M. (1970). Life tables up to age 10 for mongols with and without congenital heart defect. Fournal of Mental Deficiency Research, 14, 235.

Ipsen, J., and Feigl, P. (1970). (Eds.) Bancroft's Introduction to Biostatistics, 2nd ed. Harper and Row, New York,

Keith, J. D., Rowe, R. D., and Vlad, P. (1958). Heart Disease in Infancy and Childhood. Macmillan. New York.

Kidd, L., Rose, V., Collins, G., and Keith, J. (1965). The hemodynamics in ventricular septal defect in childhood. American Heart Fournal, 70, 732.

Kreutzer, E. A., Garber, V. A., Coronel, A. R., Pedrini, M., and Parente, A. D. G. (1973). Relation between mongolism and pulmonary hypertensive disease in patients under 5 years of age with septal defects between high pressure chambers [in Spanish.] Archivos del Instituto de Cardiologia de Mexico, 43, 692.

Liu, M. C., and Corlett, K. (1959). A study of congenital heart defects in mongolism. Archives of Disease in Childhood, 34, 410.

Oster, J. (1956). The causes of mongolism. Danish Medical Bulletin, 3, 158.

Øster, J. (1953). Mongolism. Munksgaard. Copenhagen.

Plett, J. A., Tandon, R., and Moller, J. H. (1974). Hypertensive pulmonary vascular disease. Archives of Pathology, 97, 187.

Rowe, R. D. (1962). Cardiac malformation in mongolism. American Heart fournal, 64, 567.

Rowe, R. D., and Uchida, I. A. (1961). Cardiac malformation in mongolism. American fournal of Medicine, 31, 726.

Shaher, R. M., Farina, M. A., Porter, I. H., and Bishop, M. (1972). Clinical aspects of congenital heart disease in mongolism. American fournal of Cardiology, 29, 497.

Soudon, P., Stijfns, M., Tremouroux-Wattiez, M., and Vliers, Ä. (1975). Precocity of pulmonary vascular obstruction in Down's syndrome. European fournal of Cardiology, 2, 473.

Tandon, R., and Edwards, J. E. (1973). Cardiac malformations associated with Down's syndrome. Circulation, 47, 1349.

Requests for reprints to Dr. H. Baekgaard Laursen, Department of Cardiology, University Hospital, 8000 Arhus C, Denmark. 